interactions of these substances with calcium and magnesium carbonates, e.g.

$$
\begin{gathered}
2 \mathrm{NaCl}+\mathrm{CaCO}_{3} \rightleftarrows \mathrm{Na}_{2} \mathrm{CO}_{3}+\mathrm{CaCl}_{2} \\
2 \mathrm{NaCl}+\mathrm{CaCO}_{3}+\mathrm{CO}_{2}+\mathrm{H}_{2} \mathrm{O} \rightleftarrows 2 \mathrm{NaHCO}_{3}+\mathrm{CaCl}_{2} \\
\mathrm{Na}_{2} \mathrm{SO}_{4}+\mathrm{CaCO}_{3} \rightleftarrows \mathrm{Na}_{2} \mathrm{CO}_{3}+\mathrm{CaSO}_{4},
\end{gathered}
$$

but it is not easy to understand how such interchanges could result in the production of more than a mere trace of the alliali. A more probable explanation assumes as the first stage a reduction of sulphate to sulphide by organic matter, living or dead, with a subsequent displacement of sulphuretted hydrogen by carbonic acid :-

$$
\begin{gathered}
\mathrm{Na}_{2} \mathrm{SO}_{4}-40=\mathrm{Na}_{2} \mathrm{~S}, \\
\mathrm{Na}_{2} \mathrm{~S}+\mathrm{CO}_{2}+\mathrm{H}_{2} \mathrm{O}=\mathrm{Na}_{2} \mathrm{CO}_{3}+\mathrm{H}_{2} \mathrm{~S}, \& \mathrm{c} .
\end{gathered}
$$

In support of this view there are quoted statements by Lunge that the springs "are full of algæ," that "at a distance of three feet from their origin they begin to give off sulphuretted hydrogen," and that the "odour becomes more intense a little further on, but ceases at a greater distance."

The Wadi Natrun deposits were probably the oldest known occurrence of natural soda in the world, and they constituted the principal source of supply of that commodity for thousands of years. They are at present worked by the Egyptian Salt and Soda Company, who took them over from the Société Anonyme des Soudes naturelles d'Egypte, to which latter company the Government had granted at the end of 1897 a concession for fifty years. The company makes caustic soda and soda ash, and, in addition, extract and sell both natrun (raw soda) and salt. According to the customs returns the exports include 1200 tons of caustic soda, value about ro,oool., and ahout 800 tons of natrun. But both these products are sold also for use in the country, and the company uses considerable quantities of caustic soda at its own soap factory.

The Wadi Natrun is connected with the State railway system by means of a narrow-gauge railway 50 kilometres long, running from Khatatbs to the rentrë of the Wadi.

T. M. L.

\section{AGRICULTURE IN INDIA.}

THE Agricultural Journal of India (vol. vii., part iv.) contains several articles which testity to the assiduity with which various questions are being investigated. Dr. C. A. Barber contributes a paper on seedling canes in India, and gives a brief outline of the chief phases in the cane-sugar industry and the causes which led to the raising of seedling canes in Java and Barbados. Similar work has been carried out in India, and records are being accumulated, in order to afford data for a general classification of the canes of the country. Difficulty was experienced in procuring sugar-cane arrows with a fair proportion of anthers containing fully matured pollen; in fact, the only native cane possessing this property was the Cheni of Mysore.

Mr. C. E. Low writes on the supply of agricultural cattle in India, and after giving statistical information and a description of the present situation regarding cattle supply, with an examination of the various features involved, discusses the question of the food supply in times of famine and the measures which the Government is adopting to cope with various causes which tend to a diminution in the number or efficiency of agricultural cattle. It is interesting to note, in connection with the storage of fodder as reserves for seasons of famine, that "the main objection to this proposal in the popular mind seems to be that the possession of stored fodder tempts a hostile neighbour to revenge himself by setting light to the stack."

Messrs. E. J. Woodhouse and T. Bainbrigge NO. 2254, VOL. 90]
Fletcher report the adoption of systematic hand-picking of the caterpillars of Agrotis ypsilon, and the use of the Andres Maire moth-trap in the Mokameh Tal. During the season of rgII upwards of 60,000 caterpillars were hand-picked, and 2000 Agrotis moths were caught in November by one trap. It is estimated that by the above means 6000 acres of crops were saved.

Mr. F. M. Howlett discusses the possibility of the introduction of yellow fever consequent on the opening of the Panama Canal and the shortened route from the fever-zone in the West Indies and Central America. It is pointed out that, if yellow fever were introduced, and Stegomyia fasciata proved to be the only effective carrier, the disease would be more or less confined to the coast districts and seaport towns, while if $S$. scutellaris also proved effective, there is no reason why it should not spread infection throughout the country. The distribution of the different species of Stegomyia in the larger seaports is now being ascertained by means of a systematic survey.

\section{NATURAL SCIENCE PAPERS AND MEMOIRS}

$\mathrm{I}$ the sixth volume of Fortschritte der naturwissenschaftichen forschung, Prof. W Halbfass reviews the recent work on the topography, hyarography, and geology of the lakes of Asia, Atrica, America, and Australia. Dr. A. Rühl, in his paper on a new method in geomorphology, pleads for the application of the derluctive method to the borderland between topographical geology and geography. The exposition of the peneplain theory of Prof. Davis, as well as of other points bearing on normal marine, glacial, and arid cycles, is illustrated by photographs and diagrams. The results of recent researches in radio-activity, particularly on uranium, thorium, and actinium, form the subject of a review by Prof. Otto Hahn and Dr. L. Meitner.

In the same volume the classification of functional mental disorders, and the existence of fundamental differences, between organic and functional psychoses, are discussed by Prof. O. Bumke. The problem of regeneration, in its inorganic, botanical, and zoological aspects, is surveyed by Prof. D. Barfurth, who appends to his memoir a selected bibliography containing about 500 references. After examining the various theories of regeneration, he regards that of Roux as being most nearly in accord with the facts observed, i.e. that, in cases where regeneration can take place, disturbance of the living organism in an adult individual gives rise to formative stimuli in the reserve germ-plasm of the adult cells or of cells not yet fully differentiated, which lead to the re-establishment of the organism as a whole. Dr. W. Hausmann, in a paper on optical "sensibilisators" in plants and animals, concludes that several pigments which occur commonly in nature are photo-biological "sensibilisators," which react under definite physiological and pathological conditions.

Dr. W. G. van Name (in Proc. Boston Soc. Nat. Hist., vol. xxxiv., pp. 4I3-6ig, plates 43-73) gives an account of the simple Ascidians of the region from the Gulf of St. Lawrence to Long Island Sound. This coast is not rich either in number of species of Ascidians or in those presenting striking structural characters. Leaving out of account all uncertain forms, thirty-four species (seven of which are new) are recorded. The genus Bostrichobranchus, known only from the Atlantic coast of North America, is the most interesting Ascidian described in this memoir. Dr. van Name regards this as the most highly specialised genus of Ascidians, and as having been derived from the genus Eugyra. 